\title{
EFFECT OF DROUGHT/IRRIGATION ON PROXIMATE COMPOSITION AND CARBOHYDRATE CONTENT OF TWO ENSET [ENSETE VENTRICOSUM (WELW.) CHEESMAN] CLONES
}

\author{
Solomon Zewdie $1,2, *$, Mats Olsson ${ }^{2}$ and Masresha Fetene ${ }^{1}$ \\ ${ }^{1}$ Department of Biology, Faculty of Science, Addis Ababa University, PO Box 30193, Addis Ababa, \\ Ethiopia. E-mail: mfetene@bio.aau.edu.et \\ ${ }^{2}$ Department of Forest Soils, Swedish University of Agricultural Sciences, PO Box 7001, SE 750 07, \\ Uppsala, Sweden. E-mail: mats.olsson@sml.slu.se
}

\begin{abstract}
Enset [Ensete ventricosum (Welw.) Cheesman] is an important root crop serving as a carbohydrate rich food source in Ethiopia. Perennial crops, like enset, are often exposed to recurrent dry periods which could greatly affect their growth, physiology and yield. The effect of induced drought/irrigation on the proximate composition and carbohydrate content of harvestable plant parts (pseudostem and corm) of two field grown enset clones (Ameratye and Yesherakinkye) was investigated. Proximate analysis showed that extended drought significantly $(\mathrm{P} \leq 0.05)$ reduced crude protein, ash content, potassium and phosphorus contents of enset pseudostem and corm of the two clones. On the other hand, crude fibber content and calcium levels were significantly higher in droughted groups than irrigated ones. There were no significant treatment effects on crude fat content and /or magnesium levels. Moreover, drought resulted in a significant increase in the level of soluble sugars and a decline in starch content of plant parts in both clones. Droughted plants accumulated 2-4 fold more soluble sugars than irrigated groups while the latter group gained $14-23 \%$ more starch. There was no significant difference between the two clones for the parameters considered. Low nutrient content of droughted plants could be the result of reduced nutrient uptake and assimilation caused by low soil water content and limited energy source (carbon skeleton). The observed increase in soluble sugars could be an indication of osmotic adjustment mechanisms in droughted enset plants. On the other hand, the decline in starch content could be due to reduced carbon assimilation and/or starch degradation.
\end{abstract}

Key words/phrases: Carbohydrates, clones, drought, enset, proximate composition

\section{INTRODUCTION}

Enset [Ensete ventricosum (Welw.) Cheesman] is a perennial, herbaceous monocot in the family Musaceae. It resembles the banana plant and is often referred to as 'false banana'. The plant is domesticated only in Ethiopia and is grown in the south and south-western parts of the country serving as a staple/co-staple food for an estimated 10-12 million people (Taye Bezuneh, 1984). Enset cultivation involves artificial induction of suckers by vegetative propagation, transplanting plants to new plots every 1 or 2 years, with occasional manuring, weeding and leaf pruning. Enset reaches maturity within 6-12 years depending on clone type and altitude. The crop traditionally grows in the middle and high altitudes that receive an annual rainfall of $1100-1500 \mathrm{~mm}$. Hundreds of clones are grown by farmers in the enset farming system.
Enset is grown mainly for its starchy food extracted from the pseudostem and the underground corm. A variety of local human foods are processed from a combination of the enset pseudostem and the underground corm. For example, boula, a starchy precipitate from the pseudostem-corm mixture, is often used in the making of porridge or mixed with wheat flour in the preparation of local gruel called 'atmit'. The fibrous, fermented product is often used to make a pancake like bread, kocho. The corm can also be eaten after being boiled ('amicho') in a manner similar to other tuber or root crops.

In recent years, enset farming has expanded to moisture stressed, low altitude areas perhaps owing to land shortage and/or owing to its acclaimed role in providing food security in the face of recurrent droughts and the accompanying crop failure. Enset plants grown in lower and parts of the middle altitude are experiencing differing

* Current address: Wondo Genet College of Forestry and Natural Resources, Hawassa University, PO Box 128, Shashemene, Ethiopia. E-mail: zew172@yahoo.com 
degrees and length of dry periods every year. The effect of drought would be detrimental particularly for young plants at early transplanting stage. Some authors (Bayush Tsegaye, 1991; Shigeta, 1990) have noted that enset tolerates short season droughts and that some clones perform relatively better under drought than others. Recently, we reported the effect of extended drought on the growth, physiology, and yield of field grown young enset plants of two enset clones (Solomon Zewdie et al., 2007). We showed that drought significantly reduced biomass production and partitioning to plant parts.

Apart from the reduction in assimilate production; moisture stress could also alter biochemical composition and nutrient contents of plant parts. These effects of water stress have important implications in terms of plant adaptive responses to drought, nutritional quality and also plant productivity in the face of drought. Information on biochemical composition and nutrient status of enset plants is scanty. The available information in this regard is limited to analysis of protein contents of different enset clones (Besrat Alemayehu, 1979), effect of fermentation length on protein levels (Taye Bezuneh, 1984) and enset starch characterization (Tsige Gebremariam and Schimdt, 1996). To date, there is no information on the effect of environmental stresses, like drought, on the carbohydrate content and/or nutrient status of enset clones. In this report, we provide information on the effect of drought/irrigation on proximate composition and carbohydrate content of harvestable plant parts of field grown plants of two enset clones.

\section{MATERIALS AND METHODS}

\section{Plant establishment and growth conditions}

Plant establishment and growth conditions are described in detail in Solomon Zewdie et al. (2007). Equal sized suckers of two enset clones Ameratye and Yesherakinkye were transplanted on a preprepared plot $\left(384 \mathrm{~m}^{2}\right)$ with a spacing of $1.5 \mathrm{~m} \times 1.5$ $\mathrm{m}$ for about 1 year. Suckers were watered twice a week during the dry period while dried manure (1 $\mathrm{kg} /$ plant) was applied every 2 months and plants were allowed to grow. One year after transplanting, plants were watered adequately to keep the soil moisture at field capacity and watering was interrupted a day before drought induction/irrigation. A stationary rain-out plastic shelter was constructed bordering the edges of the plot and covering the sides and the top with transparent plastic shutters.

Following a randomized block design, plants from each clone were then systematically divided between droughted groups and irrigated groups compartments separated with a corridor (3m). There were four treatment groups ( 2 clones $\times 2$ watering regimes) labelled as AmDR (droughted Ameratye), YkDR (droughted Yesherakinkye), AmIR (irrigated Ameratye), and YkIR (irrigated Yesherakinkye). Upon drought induction, plants in the irrigated treatment received 20 litre water every $3^{\text {rd }}$ day keeping the soil water content at field capacity throughout the experiment (90 days). Plants in the droughted treatment received no water.

\section{Sample collection and processing}

At the end of the drought period (90 days of drought/irrigation), three sample plants were harvested from each treatment group. These plants were uprooted and belowground biomass was excavated. Pseudostem discs were extracted from three points along the height of the pseudostem and dried outer sheaths were peeled off while the inner sheaths were mixed to form a composite sample. Corm samples were also taken from three different points along the circumference of the corm and were mixed. Samples were then minced into pieces and air dried immediately for $24-48 \mathrm{hr}$. Air dried samples were then ground with mortar and pestle and kept in plastic tubes.

\section{Proximate analyses}

All samples were oven-dried at $70^{\circ} \mathrm{C}$ for $48 \mathrm{~h}$ and all chemical determinations on enset corm and pseudostem samples were carried out in triplicates. Proximate analyses (crude protein, crude fat, crude fibber, and ash value) were carried out according to standard procedures (AOAC, 1990). Nitrogen was determined by the Dumas method (Leco CHN 600 Elemental Analyzer) and crude protein was calculated by multiplying the nitrogen content by a factor of 6.25 (AOAC, 1984). Nutrient concentrations including calcium, potassium, phosphorous and magnesium were determined by Plasma Emission Spectroscopy (also called inductively coupled plasma (ICP) spectroscopy) using the method of Fassel (1978).

\section{Carbohydrate analyses}

The method involves extraction of soluble sugars, solubilization of the starch followed by a two-step enzymatic conversion of the starch into glucose, 
and quantification of glucose with the hexokinase method (Brunt et al., 1998). A pre-dried sample $(0.100 \mathrm{~g})$ was dissolved in acetate buffer $(25 \mathrm{ml}$ of $0.05 \mathrm{M}, \mathrm{pH}, 5.0$ ) and water soluble carbohydrates were extracted. Part of the extract was taken for the determination of free glucose and fructose (soluble sugars). The remaining solution was then hydrolyzed with $0.100 \mathrm{ml}$ Termamyl (thermostable $\alpha$-amylase, Novo Nordisk A/S Denmark) by boiling the mixture for 30 minutes at $100^{\circ} \mathrm{C}$ with occasional shaking. After cooling and centrifugation (300rpm for 5 minutes), the hydrolysate $(0.050 \mathrm{ml})$ was then mixed with $0.200 \mathrm{ml}$ acetate buffer $(0.05 \mathrm{M})$ and $0.020 \mathrm{ml}$ of amyloglucosidase (E.C. 3.2.1.3, Boehringer Mann-heim) in glass test tube and heated $\left(60^{\circ} \mathrm{C}\right)$ in a water bath for 60 minutes. Any sucrose and fructanes in the extract for soluble sugar analysis, were further hydrolyzed to glucose and fructose by boiling $\left(80^{\circ} \mathrm{C}\right.$ for 70 minutes) the extract with $0.150 \mathrm{ml}(0.074 \mathrm{M}) \mathrm{H}_{2} \mathrm{SO}_{4}$. The soluble sugar solution and the enzyme treated mixture were separately treated as follows: $0.1 \mathrm{ml}$ of the boiled solution was mixed with tri-ethanol amine hydrochloride (TEAB) $(2.9 \mathrm{ml})$, Nicotinamideadenine dinucleotide phosphate (NADP) $(0.1 \mathrm{ml})$, Adenosine-triphosphate (ATP) (0.1ml), Phosphoglucose isomerase $(0.02 \mathrm{ml}) \quad$ (PGI; EC $\quad$ 5.3.1.9 Boehringer Mannheim) and allowed to stand for 15 minutes. The absorbance for NADPH at $340 \mathrm{~nm}$ was then measured with a Spectro-photometer (U-2000, Hitachi, VWR Inter) and recorded as initial absorbance. To this mixture, $0.02 \mathrm{ml}$ Hexokinase/glucose-6-phosphate dehydro-genase, EC 2.7.1.1/1.1.1.49, Boehringer Mannheim) was added and allowed to stand for 15 minutes and the absorbance at 340nm was again recorded as final absorbance. A correction was made so that the total soluble sugar in the total extraction volume can be calculated. The amount of starch in $\mathrm{mg}$ was calculated by multiplying the amount of glucose (in $\mathrm{mg}$ ) by a factor of 0.90 to correct the loss of water upon hydrolysis of starch. Finally, the amount of starch is expressed in percent of predried sample.

\section{Statistical analyses}

Data were subjected to one-way analysis of variance to find out significant treatment effects on carbohydrate and nutrient contents of plant parts. Mean differences were considered significant when $\mathrm{p}<0.05$.

\section{RESULTS}

\section{Mineral elements and proximate composition}

The elemental composition of enset pseudostem and corm is shown in Table 1. Irrigation had significantly increased the content of phosphorus and potassium in plant parts. In contrast, calcium content of the pseudostem and corm of irrigated plants was significantly lower than that of droughted plants. Moreover, irrigated plants had slightly lower concentration of magnesium than droughted plants although the mean difference was not significant. Among the different mineral elements, potassium represented the major fraction in plant parts regardless of the watering regime.

Table 1. Nutrient concentration in the pseudostem (A) and corm (B) of droughted (DR) and irrigated (IR) plants of two enset clones, Yesherakinkye (Yk) and Ameratye ( $\mathrm{Am})$ after 90 days of drought/irrigation.

A

\begin{tabular}{llllll}
\hline \multirow{2}{*}{ Treatments } & \multicolumn{5}{c}{ Nutrient concentration in enset pseudostem $\left(\mathrm{g} 100 \mathrm{~g}^{-1} \mathrm{DM}\right)$} \\
\cline { 2 - 6 } & Nitrogen & Phosphorous & Potassium & Calcium & Magnesium \\
\hline YkDR & $0.52(0.09) \mathrm{a}$ & $0.30(0.02) \mathrm{a}$ & $3.62(0.41) \mathrm{a}$ & $2.58(0.18) \mathrm{b}$ & $0.73(0.11) \mathrm{a}$ \\
YkIR & $0.88(0.05) \mathrm{b}$ & $0.77(0.01) \mathrm{b}$ & $5.15(0.05) \mathrm{c}$ & $1.25(0.10) \mathrm{a}$ & $0.68(0.06) \mathrm{a}$ \\
AmDR & $0.67(0.06) \mathrm{c}$ & $0.37(0.03) \mathrm{a}$ & $3.79(0.86) \mathrm{a}$ & $3.40(0.21) \mathrm{c}$ & $1.05(0.12) \mathrm{a}$ \\
AmIR & $0.96(0.03) \mathrm{b}$ & $0.88(0.01) \mathrm{c}$ & $5.12(0.48) \mathrm{c}$ & $2.45(0.26) \mathrm{d}$ & $0.99(0.10) \mathrm{a}$ \\
\hline
\end{tabular}

B

\begin{tabular}{llllll}
\hline \multirow{2}{*}{ Treatments } & \multicolumn{5}{c}{ Nutrient concentration in enset corm $\left(\mathrm{g} 100 \mathrm{~g}^{-1} \mathrm{DM}\right)$} \\
\cline { 2 - 6 } & Nitrogen & Phosphorous & Potassium & Calcium & Magnesium \\
\hline YkDR & $0.68(0.02) \mathrm{a}$ & $0.35(0.02) \mathrm{a}$ & $1.12(0.17) \mathrm{a}$ & $0.61(0.04) \mathrm{c}$ & $0.57(0.12) \mathrm{ab}$ \\
YkIR & $0.94(0.02) \mathrm{b}$ & $0.88(0.01) \mathrm{b}$ & $2.69(0.27) \mathrm{c}$ & $0.34(0.08) \mathrm{ab}$ & $0.63(0.04) \mathrm{a}$ \\
AmDR & $0.31(0.04) \mathrm{c}$ & $0.42(0.09) \mathrm{a}$ & $1.40(0.26) \mathrm{a}$ & $0.58(0.04) \mathrm{ca}$ & $0.50(0.05) \mathrm{ab}$ \\
AmIR & $0.67(0.10) \mathrm{ab}$ & $0.75(0.00) \mathrm{c}$ & $2.18(0.79) \mathrm{c}$ & $0.19(0.04) \mathrm{b}$ & $0.38(0.05) \mathrm{b}$ \\
\hline
\end{tabular}

Note: a Values are mean and S.E. $n=3$. Values in the same column followed by same letter(s) do not differ significantly $(\mathrm{P}<0.05)$. 
There were significant treatment effects on proximate composition (Table 2) of plant parts. However, there was no significant difference between the two enset clones in this respect. Protein and ash value of the pseudostem and corm of irrigated plants were significantly higher than that of droughted plants. Crude protein content in irrigated plants was $31-54 \%$ higher than that in droughted plants. Moreover, irrigated plants had up to $40 \%$ higher ash value than droughted plants and the pseudostem had significantly higher ash value than the corm. However, there was no significant difference in protein contents between the pseudostem and the corm for the enset clone Yesherakinkye. There was no significant treatment effects on crude fat content of plant parts except that droughted groups had a higher mean value than irrigated groups. On the other hand, crude fibber content of plant parts was significantly higher $(68-82 \%)$ in droughted than in irrigated plants.

\section{Carbohydrates}

There were significant treatment effects on soluble sugars and starch contents in plant parts (Fig 1). After 90 days of drought, droughted plants accumulated 2-4 times more soluble sugar than irrigated plant parts. The mean difference between the two groups was statistically significant. There was no apparent difference between the pseudostem and the corm in soluble sugar concentration. In contrast, irrigation significantly increased the starch content of both the pseudostem and corm. Irrigated plants had 12$28 \%$ more starch than droughted plants. The enset clone Ameratye had a slightly more starch than the clone Yesherakinkye. Moreover, irrespective of treatment type starch content of the pseudostem was lower than that in the corm. There was no significant difference between the two clones.
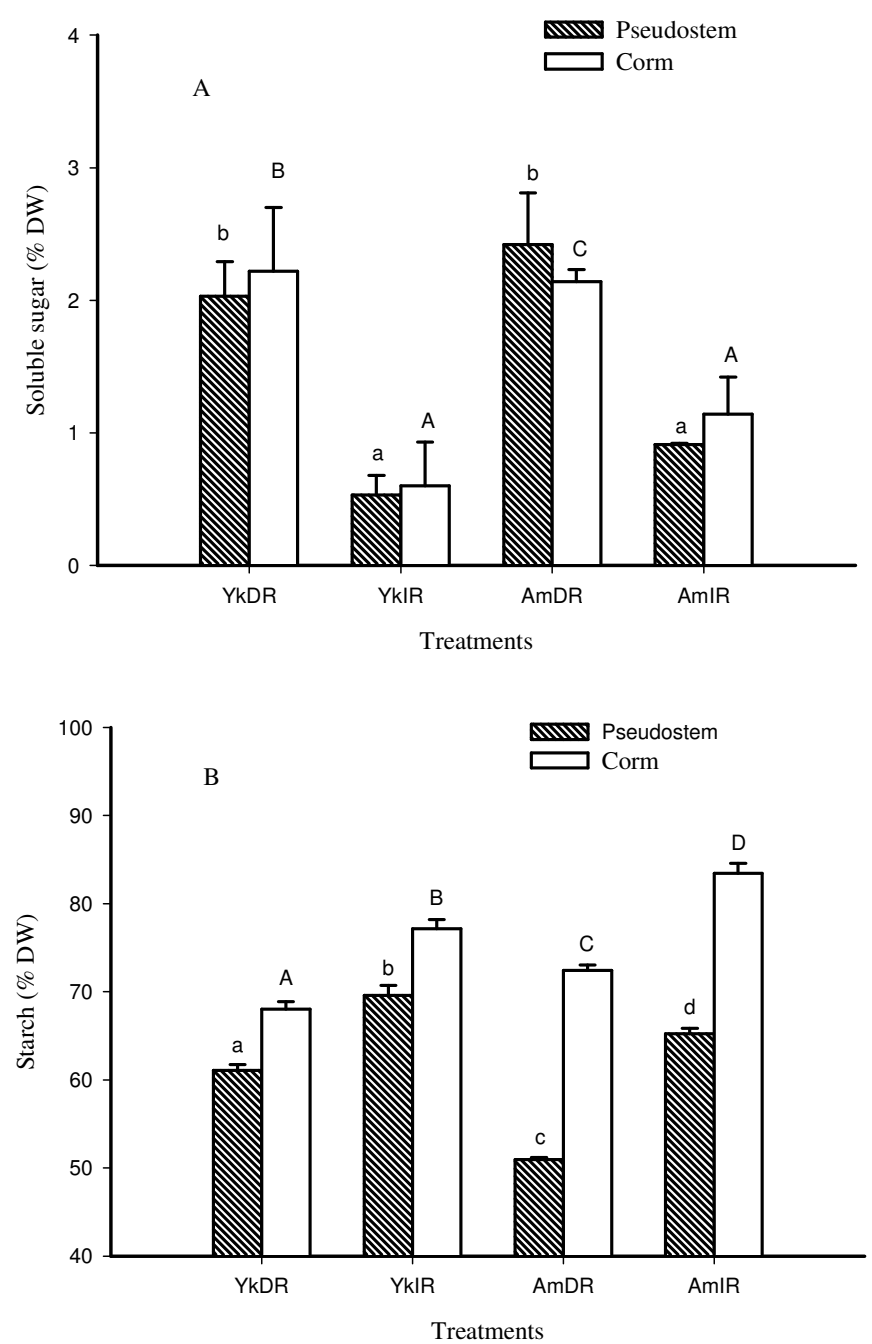

Fig. 1. Soluble sugars (A) and starch (B) content of pseudostem and corm of droughted (DR) and irrigated (IR) plants of two enset clones; Yesherakinkye (Yk) and Ameratye (Am) after 90 days of drought/irrigation. Bars are mean and S.E. $n=3$. Bars with same letter do not differ significantly. Note that statistical comparisons are made among treatments for a given plant part. 
Table 2.. Proximate composition of the pseudostem (A) and corm (B) in droughted (DR) and irrigated (IR) plants of two enset clones, Yesherakinkye (Yk) and Ameratye (Am) after 90 days of drought/irrigation. A

\begin{tabular}{lllll}
\hline \multirow{2}{*}{ Treatments } & \multicolumn{4}{c}{ Proximate composition of the pseudostem $\left(\mathrm{g} 100 \mathrm{~g}^{-1} \mathrm{DM}\right)$} \\
\cline { 2 - 5 } & Crude protein & Crude fat & Crude fibber & Ash \\
\hline YkDR & $3.25(0.68) \mathrm{a}$ & $0.55(0.06) \mathrm{a}$ & $18.68(0.78) \mathrm{b}$ & $8.87(0.54) \mathrm{a}$ \\
YkIR & $5.51(0.34) \mathrm{b}$ & $0.54(0.04) \mathrm{a}$ & $5.83(0.49) \mathrm{a}$ & $10.97(0.34) \mathrm{b}$ \\
AmDR & $4.16(0.43) \mathrm{ac}$ & $0.67(0.08) \mathrm{a}$ & $23.24(1.28) \mathrm{b}$ & $9.21(0.42) \mathrm{a}$ \\
AmIR & $6.02(0.21) \mathrm{b}$ & $0.53(0.02) \mathrm{a}$ & $6.23(0.65) \mathrm{a}$ & $11.55(0.36) \mathrm{b}$ \\
\hline
\end{tabular}

B

\begin{tabular}{lllll}
\hline \multirow{2}{*}{ Treatments } & \multicolumn{5}{c}{ Proximate composition of the corm $\left(\mathrm{g} 100 \mathrm{~g}^{-1} \mathrm{DM}\right)$} \\
\cline { 2 - 5 } & Crude protein & Crude fat & Crude fibber & Ash \\
\hline YkDR & $4.22(0.13) \mathrm{a}$ & $0.53(0.05) \mathrm{ab}$ & $17.49(0.64) \mathrm{b}$ & $3.36(0.16) \mathrm{a}$ \\
YkIR & $5.90(0.14) \mathrm{c}$ & $0.36(0.03) \mathrm{bc}$ & $5.45(0.28) \mathrm{a}$ & $5.64(0.33) \mathrm{c}$ \\
AmDR & $1.93(0.26) \mathrm{b}$ & $0.50(0.08) \mathrm{bc}$ & $15.00(0.68) \mathrm{b}$ & $3.07(0.23) \mathrm{a}$ \\
AmIR & $4.19(0.63) \mathrm{c}$ & $0.28(0.02) \mathrm{a}$ & $2.97(0.45) \mathrm{c}$ & $4.71(0.20) \mathrm{b}$ \\
\hline
\end{tabular}

Note: a Values are mean and S.E. $\mathrm{n}=3$. Values in the same column followed by same letter(s) do not differ significantly $(\mathrm{P}<0.05)$.

\section{DISCUSSION}

Mineral contents and proximate composition The significant decline in ash value of the enset corm and pseudostem in droughted plants could generally be the result of reduced nutrient availability and uptake with increasingly drying soil. Our observation is in agreement with the observations of Onwugbuta-Enyi (2004) where the ash value of stressed cowpea seedlings was $50 \%$ of that in well-watered plants after a stress period of 5 weeks. Reduced soil nutrient availability due to drought is frequently observed (Chapin, 1991). Nutrient uptake may be reduced both from impairment of absorption processes in the root and from decreased mobility of ions with a drop in soil water content (Russell, 1973; Dunham and Nye, 1976). Moreover, active uptake of mineral ions (e.g., potassium) may be limited by reduced energy substrate (carbohydrate) supply from leaves which could be the case in water stressed plants. Drought also affected macronutrient content in the pseudostem and corm of the two enset clones. The concentration of potassium and phosphorous was significantly higher in irrigated plants than in droughted groups. A similar observation has been reported by El-Sharkaway and Cadavid (2002) on field grown cassava. Drought may affect the nutritional status in plants at the level of nutrient uptake and long distance transport in xylem and phloem (Hsiao, 1973). The effect of drought on plant nutrition may also be related to reduced energy availability for assimilation of carbon, nitrogen, phosphorous and sulphur, since most of the initial form taken up must be converted in energy dependent processes before these elements can be used for growth and development of plants (Grossman and Takahashi, 2001).

On the other hand, the level of calcium increased significantly in droughted enset plants than in irrigated plants also the level of magnesium tended to be generally higher in the former although the difference was not significant. Our results are in agreement with the observation of Thomas (1991) on pot grown swards of Lolium perenne L. where calcium and magnesium accumulated in the leaf while phosphate level drop from $40 \mu \mathrm{mol} \mathrm{g}{ }^{-1} \mathrm{DM}$ to about $10 \mu \mathrm{mol} \mathrm{g}{ }^{-1} \mathrm{DM}$ after 8 weeks of drought. According to Pitman (1981), potassium and phosphate uptake from drying soil may be saturated, inversely proportional to concentration and therefore reduced during drought; whereas sodium and calcium uptake may be proportional to concentration and therefore increase with drought. However, El-Sharkaway and Cadavid (2002) observed a decline in calcium content of cassava root and stem subjected to 3 months of induced drought in the field.

We observed that irrigated enset plants had significantly higher total protein content than droughted groups. Reduced mobility due to drought is particularly important for nitrate ions, which are transported from the bulk soil to the root surface mainly through mass flow (Marschner, 1995). Besides limiting the acquisition of nitrate by roots (BassiriRad and Caldwell, 1992), drought 
may also restrict the ability of plants to reduce and assimilate nitrogen as a result of inhibition of the activities of enzymes involved in nitrogen metabolism (Correia et al., 2005). Thus, the lower crude protein content (i.e., low nitrogen content) could be the result of one or more effects of drought stress on nitrogen mobility, uptake and assimilation. On the other hand, our results indicated that fibber content of droughted enset plants was significantly higher than that of irrigated plants. Our finding contrasts with the observation of Pessarkhli et al. (2005) who found no difference in straw fibre contents of wheat and barely plants subjected to two levels of water stress and of Suarez (2005) who observed significantly higher fibber content of Mangrove (Avicennia germinans L.) leaves for the wet period than the dry period.

\section{Carbohydrates}

The observed increase in soluble sugars in droughted enset plants could be an adaptive biochemical response to extended (severe) drought. The rise in soluble sugar in droughted plants was accompanied by a decline in starch content in the respective plant tissues. Decreased starch levels are often the result of both decreased starch formation and increased starch degradation (Keller and Ludlow, 1993). Our observation may imply that the increased sugar level in droughted plants could be the result of starch degradation although the decline in starch levels can not fully account for the observed rise in soluble sugars. Water stress is known to alter physiological and biochemical processes in plants. Drought induced increase in the levels of metabolites such as sugars and amino acids (e.g., proline) have been well documented (e.g., Irigoyen et al., 1992; Keller and Ludlow, 1993; Rekika et al., 1998; Sanchez et al., 1998; Bajji et al., 2001). The accumulation of these metabolites under drought is often considered as an adaptive physiological response that minimizes the deleterious effects of water stress (Morgan, 1984; Rekika et al., 1998) through osmotic adjustment. The general decline in starch levels in droughted plants could be the consequence of a decline in carbon assimilation due to drought (Solomon Zewdie et al., 2007). However, one important observation in relation to the effect of drought on starch partitioning in enset plant parts was that the starch content of the corm is less affected than that of the pseudostem. In relation to this, we observed in our previous work (Solomon Zewdie et al., 2007) that droughted enset plants proportionally accumulated more biomass to belowground parts. This altered partitioning that favours the corm may result in the accumulation of more starch in the corm than in the pseudostem despite the stress condition.

The present study showed that extended dry period can significantly alter the physiological and biochemical processes in enset plants and in effect the nutritional composition of enset plant parts. Moisture stress caused a decline in nutrient assimilation and reduced ash value of the pseudostem and the corm. Particularly, the drop in crude protein content following a stress period could be crucial as enset protein content is generally low. Enset is grown for its starchy food, from the pseudostem and the corm. Consequently, the negative effect of drought in starch accumulation would result in enset food yield decline. On the other hand, despite the severity of the stress, the decline in starch content was moderate. This study has also showed, for the first time, the effect of extended drought on carbohydrate levels of enset plants. The significant increase in the level of soluble sugars could be a possible adaptive response to drought which may imply the role of these metabolites in osmotic adjustment and thus conferring drought tolerance (osmotic adjustment) in enset plants.

\section{ACKNOWLEDGEMENTS}

This study was financially supported by the Swedish International Development Agency (SIDA) through the Swedish Agency for Research Cooperation (SAREC) and Addis Ababa University, Ethiopia. The authors thank Mr. Mohammed Bigee of Agri-Lab., Uppsala, Sweden, for the nutrient and carbohydrate analysis.

\section{REFERENCES}

1. AOAC (1984). Official Methods of Analysis (14th ed.), Association of Official Analytical Chemists, Washington DC.

2. AOAC (1990). Official Methods of Analysis of the Association of Official Analytical Chemists. Association of Official Chemists, Arlington, VA, 50th ed. Vol. 2, p. 703. 
3. Bajji, M., Lutts, S. and Kinet, J-M. (2001). Water deficit effects on solute contribution to osmotic adjustment as a function of leaf ageing in three durum wheat (Triticum durum Desf.) cultivars performing differently in arid conditions. Plant Science 160:669-681.

4. BassiriRad, H. and Caldwell, M.M. (1992). Root growth, osmotic adjustment and $\mathrm{NO}_{3}$ uptake during and after a period of drought in Artemisia tridentata. Australian Journal of Plant Physiology 19:493-500.

5. Bayush Tsegaye (1991). Community management of crop genetic resources in the enset complex farming system of southern Ethiopia: a case study from Sidama Region. Masters Thesis. Agricultural University of Norway.

6. Besrat Alemayehu, Mehansho Habtu. and Taye Bezuneh (1979). Effect of varietal difference and fermentation on protein quantity and quality of ensete. Nutrition Reports International 20(2):245250.

7. Brunt, K., Sanders, P. and Rozema, T. (1998). The enzymatic determination of starch in food, feed and raw materials of the starch industry. Starch/Stärke 50(10):413-419.

8. Chapin, F.S. (III) (1991). Effects of multiple environmental stresses on nutrient availability and use. In: Response of Plants to Multiple Stresses, pp. 67-88, (Monney, H.A., Winner, W.E. and Pell, E.J., eds). Academic Press, San Diego.

9. Correia, M.J., Fonesca, F., Azedo-Silva, J., Dias, C., David, M.M., Barrote, I, Osorio, M.L. and Osorio, J. (2005). Effects of water deficit on the activity of nitrate reductase and content of sugars, nitrate and free amino acids in the leaves and roots of sunflower and white lupin plants growing under two nutrient supply regimes. Physiologia Plantarum 124:61-70.

10. Dunham, R. J. and Nye, P. H. (1976). The influence of soil water content on the uptake of ions by roots. III. Phosphate, potassium, calcium and magnesium uptake and concentration gradients in soil. Journal of Applied Ecology 13:967-984.

11. El-Sharkaway, M.A. and Cadavid, L.F. (2002). Response of cassava to prolonged water stress imposed at different stages of growth. Experimental Agriculture 38:333-350.

12. Fassel, V.A. (1978). Quantitative elemental analyses by plasma emission spectroscopy. Science 202(364):183-191.

13. Grossman, A. and Takahashi, H. (2001). Macronutrient utilization by photosynthetic eukaryotes and the basic fabric of interactions. Annual Review of Plant Physiology Plant Molecular Biology 52:163-210.
14. Hsiao, T.C. (1973). Plant responses to water stress. Ann. Rev. Plant Physiol. 24:519-570.

15. Irigoyen J.J, Emerich, D.W. and Sanchez-Diaz, M. (1992). Water stress induced changes in concentrations of proline and total soluble sugars in nodulated alfalfa (Medicago sativa) plants. Physiologia Plantarum 84:55-60.

16. Keller, F. and Ludlow, M.M. (1993). Carbohydrate metabolism in drought-stressed leaves of pigeon pea (Cajanus cajan). Journal of Experimental Botany 44(265):1351-1359.

17. Marschner, H. (1995). Mineral Nutrition of Higher Plants, $2^{\text {nd }}$ ed. Academic Press Ltd, London

18. Morgan, J.M. (1984). Osmoregulation and water stress in higher plants. Annual Review of Plant Physiology 35:299-319.

19. Onwugbuta-Enyi, J. (2004). Water balance and proximate composition in cowpea (Vigna unguiculata (L.) Walps.) seedlings exposed to drought and flooding stress. Journal of Applied Sciences and Environmental Management 8(2):5557.

20. Pessarakali, M.M., Morgan, P.V. and Gilbert, J.J. (2005). Dry-matter yield, protein synthesis, starch, and fibre content of barley and wheat plants under two irrigation regimes. Journal of Plant Nutrition 28:1227-1241.

21. Pitman, M.G. (1981). Ion uptake. In: The Physiology and Biochemistry of Drought Resistance in Plants, pp. 71-96, (Paleg, L.G. and Aspinall, D., eds). Academic Press, Sydney.

22. Rekika, D., Nachit, M.M., Araus, I.L. and Monneveux, P. (1998). Effect of water deficit on photosynthetic rate and osmotic adjustment in tetraploid wheats. Photosynthetica 35:129-138.

23. Russell, E. W. (1973). Soil Conditions and Plant Growth, $10^{\text {th }}$ ed. Longman, London.

24. Sanchez, F.J., Manzanares, M., Andres, E. F., Tenorio, J.L. and Ayerbe, L. (1998). Turgor maintenance, osmotic adjustment and soluble sugar and praline accumulation in 49 pea cultivars in response to water stress. Field Crops Research 59:225-235.

25. Shigeta, M. (1990). Folk in situ conservation of enset [Ensete ventricosum (Welw.) Cheesman]: Towards the interpretation of indigenous agricultural science of the Ari, southwestern Ethiopia. African Studies Monographs, Kyoto 10:93-107.

26. Solomon Zewdie, Olsson, M. and Masresha Fetene (2007). Growth, gas exchange, chlorophyll a fluorescence, biomass accumulation and partitioning in droughted and irrigated plants of two enset [Ensete ventricosum (Welw.) Cheesman] clones. Journal of Agronomy 6(4):499-508. 
27. Suarez, N. (2005). Leaf construction cost in Avicennia germinans as affected by salinity under field conditions. Biologia Plantarum 49(1):111-116.

28. Taye Bezuneh (1984). Evaluation of some Ensete ventricosum clones for food yield with emphasis on the effect of length of fermentation on carbohydrate and calcium content. Tropical Agriculture (Trinidad) 61(2):111-116.
29. Thomas, H. (1991). Accumulation and consumption of solutes in swards of Lolium perenne during drought and after re-watering. New Phytologist 118:35-48.

30. Tsige Gebremariam and Schmidt, P.C. (1996). Isolation and physico-chemical properties of enset starch. Starch/Stärke 48(6):208-214. 